\author{
Колесник В.I. \\ кандидат економічних наук, доцент \\ кафедра управління бізнесом \\ Одеська національна академія харчових технологій \\ вул. Канатна, 112, м. Одеса, Україна, 65039 \\ E-mail: brig_od@i.ua
}

\title{
УПРАВЛІННЯ СТАРТАПАМИ В УКРАЇНІ: ПРОБЛЕМИ ТА ПЕРСПЕКТИВИ
}

В статті розглянуто особливості теорії та практики управління стартапами в Україні. Визначаються проблеми сьогодення, які пов'язані з функціонуванням стартапів, окреслюються шляхи подолання вказаних проблем. Запропоновано системний підхід до підвищення ефективності управління стартапами, обґрунтовано перспективність його опрацювання з позицій реалізації інноваційного потенціалу економіки України.

Ключові слова: стартап, управління, ефективність стартапів, проблеми стартап-діяльності, перспективи стартапів в Україні.

This work is licensed under a Creative Commons Attribution 4.0 International License http://creativecommons.org/licenses/by/4.0/

Постановка проблеми та її зв'язок 3 важливими науковими та практичними завданнями. Проблеми науково-методологічного рівня пов'язані перш за все $з$ неоднозначністю тлумачення категорії «стартап», що випливає 3 іноземного походження слова. Це породжує різноманітні варіанти інтерпретації даної категорії як в наукових колах, так і серед практиків бізнесу i, як наслідок, гальмує розвиток дослідницької роботи та ускладнює управління стартапами на практиці.

Аналіз останніх публікацій по проблемі. Дослідженням стартапів присвячено праці таких науковців, як С. Бланк [1], Б. Дорф [1], Е. Райз [10], П. Тіль [9], Н. Івашова [3], Д. Збанацький [2], О. Мрихіна [7], Ф. Лалу [6]. Проте в цілому публікації стосовно стартапів, а тим більш в Україні, є фрагментарними та такими, що не надають вичерпної інформації про всі елементи процесу управління ними. Це вказує на актуальність подальших досліджень стартапів та особливо специфіки менеджменту стартапів в УкраїHi.

Формулювання цілей дослідження. Необхідно проаналізувати науково-прикладні аспекти управління стартапами в Україні: уточнити визначення стартапу та його ознаки; систематизувати коло проблем теорії та практики управління стартапами; окреслити перспективи розвитку стартапів в Україні та актуальність професіоналізації управління ними.

Виклад основних результатів та їх обгрунтування. Стартап - відносно нове явище в українській економіці. Його сутність, специфіку функціонування та управління українська бізнес-спільнота вивчає 3 досвіду закордонних бізнесменів, які почали оперувати даною категорією ще в першій половині XX ст.: студенти Стенфордського університету поз- начали словом «стартап» бізнес $з$ розробки обчислювальних машин, а деякі часописи як-от «Forbes», «Business Week» наприкінці 70-х років використовували дану категорію для опису нестандартних фінансових проектів 3 високим прибутком. Це 3 одного боку ускладнює розуміння та інтерпретацію технологій роботи зі стартапами в умовах економіки України, а $з$ іншого - показує вигоди для всіх контактних аудиторій мікро- та макро- середовища, дає можливість проаналізувати закордонний досвід управління стартапами і з урахуванням цього розробити власну модель ефективного управління стартапами саме в українських реаліях бізнесу. Саме через новизну і, як наслідок, недостатню категорійно-процесну дослідженість стартапу в Україні відсутня офіційна статистика, пряме законодавче регулювання, відповідна державна політика в сфері стартапів. Виходячи з таких міркувань, вбачається за доцільне дослідити в першу чергу сутність стартапу як економічної категорії, для чого необхідно окреслити його ознаки.

Ознаки стартапу:

- носії бізнес-ідеї (стартапери) не завжди є (будуть) керівниками реально працюючого підприємства;

- носії бізнес-ідеї зазвичай шукають інвестора (покупця бізнесу) для практичної реалізації своєї ідеї;

- інвестування в стартап пов'язане з суттєвим ризиком, тому часто виникає потреба співпраці команди стартапу з венчурними інституціями економіки;

- бізнес-модель, яка трансформуватиме ідею в реально працюючий бізнес, повинна мати схильність до масштабування - це необхідна умова лік відності стартапу як товару на ринку, один з найпер- 
ших інтересів потенційного покупця стартапу;

- мета стартапу в класичному іiі варіанті продаж бізнесу (працюючої бізнес-моделі);

- зазвичай над стартапом працює міжфункціональна команда в умовах невизначеності.

Вищенаведений перелік ознак не є вичерпним, але таким, що дозволяє однозначно трактувати самі ознаки і таким, що ігнорує популярні та водночас абстрактні характеристики, як-от: «швидка віддача вкладених коштів», «наявність ідеї, якої раніше не було» [2], «нещодавно створена компанія» [7], «креативне середовище», «новий інноваційний бізнес як результат» тощо. Розглядаючи подібні характеристики з позицій здорового глузду взагалі та професійного менеджменту зокрема, незрозуміло, що вважати швидкою віддачею, а що ні; як на практиці відрізнити креативне середовище роботи від некреативного, новий інноваційний бізнес від ненового, нещодавно створену компанію від давно створеної? Тому вважаємо віднесення подібних ознак до специфічних характеристик стартапів не логічним та позбавленим науково-практичного сенсу.

В результаті аналізу наведених вище ознак та існуючих визначень стартапу є можливим уточнення визначення даної категорії в такій редакції: стартап це будь-який реально працюючий в умовах невизначеності бізнес протягом перших шести місяців від його заснування, а також (або) продукт у вигляді бізнес-моделі, мета якого - майбутня трансформація певної бізнес-ідеї стартаперів на підприємстві потенційного інвестора (покупця) стартапу. Аргументами на користь такого визначення є те, що:

1) Найближчими українськими відповідниками англійському дієслову «start up» є дієслова починати, запускати, зачинати. Починати реалізацію нової справи неможливо вічно. Так само, як новий гравець будь-якої команди не може бути без кінця молодим та перспективним новачком, так і новий бізнес може називатися стартапом лише певний час від свого зачину. Піврічний термін (принаймні в Україні) як часова ознака віднесення бізнесу до стартапу є достатнім для апробації конкурентоспроможності бізнесу. Звичайно, деякі особливо наукоємні проекти можуть тривати роками, оскільки залежать від результатів наукового пошуку, які в свою чергу детерміновані багатьма чинниками. В таких випадках логічніше було б іменувати такі проекти саме проектами, а не «вічними» стартапами.

2) Рушій конкурентоспроможності - інновації, джерело інновацій - зміни. Будь-який новий бізнес апріорі відрізняється від інших, навіть собі подібних - це означає, що він $є$ в будь-якому разі інноваційним. Безумовно, стартап в класичному своєму розумінні (оскільки історично так склалося, що саме проекти в галузі інтернет-технологій та обчислювальних машин називали стартапами) - наукоємний проект, рушієм якого є значні досягнення науки на рівні винаходів, відкриттів, котрі потім комерціалізує стартап. Прикладом такого стартапу в галузі харчових технологій може бути стартап ініціативної групи FAIRR 3 виробництва штучного м'яса. Наразі до складу FAIRR входить 71 інвестор з сумарним капіталом 1,9 трл. доларів США. Технологія передбачає розробку спеціальних лабораторних методик вирощування м'яса 3 тваринних клітин, які отримано 3 сироватки крові [4].

Проте, $з$ іншого боку, навіть такий звичний продукт, як пакет молока, що продається в магазині $€$ інноваційним продуктом, оскільки попит на нього формують саме зміни, які було закладено виробником і які чимось вирізняють його 3-поміж інших в очах покупця, а значить цей продукт теж є інноваційним i може за наявності інших ознак бути стартапом.

3) Бізнес-середовище сьогодення в Україні настільки мінливе та ризикове саме по собі, що будьякий бізнес апріорі $є$ ризиковим, тобто вважається, що немає необхідності виділяти як обов'язкову умову віднесення бізнесу до стартапу - венчурний, ризиковий характер діяльності.

Окрім дискусійності деяких аспектів сутності та ознак, ефективну стартап-діяльність в Україні гальмує низка проблем системного характеру. Ці проблеми пов'язані здебільшого з управлінням і можуть бути вирішені за рахунок професіоналізації управління ними. 3-поміж основних проблем вбачається за необхідне виділення наступних:

1. Відсутність механізму державного управління стартап-діяльністю. Аби повністю використати потенціал стартапу як каталізатора розвитку економіки країни та засобу дифузії інновацій держава повинна розробити механізм управління стартапами. На сьогодні можна констатувати невідповідність державної політики потребам та ініціативам стартаперів, яка не тільки не сприяє, а й ускладнює реалізацію нових бізнес-проектів. Прикладом може бути ситуація початку 2017 року, пов'язана із змінами в законодавстві стосовно оподаткування підприємців, коли через зміну порядку сплати єдиного соціального внеску спостерігалося масове закриття бізнесу фізичними особами-підприємцями. Даний приклад є показовим, оскільки кожна фізична особа-підприємець, яка згорнула підприємницьку діяльність або не розпочала iii - це мінус потенційний стартап. Це означає, що першочерговою вимогою до даного механізму є простота та послідовність: закріплення категорії «стартап» у законодавстві, оптимізація режиму оподаткування для стартапів.

2. Корумпованість органів державної влади, які пов'язані 3 залученням інвестицій в українську економіку.

3. Суттєвий рівень монополізації багатьох сфер бізнесу, як правило, представниками олігархічно-політичних кіл, які не зацікавлені в нових стартапах (особливо іноземних), оскільки вважають це прямою загрозою своєму монополізованому та часто низькоконкурентному бізнесу.

4. Значна тінізація, не публічний характер угод на ринку стартапів. У 2016 році в Україні було укладено 87 інвестиційних угод з українськими інноваційними компаніями, що на $32 \%$ більше за показник попереднього року - такі дані представила в своєму щорічному огляді Українська асоціація венчурно- 
го капіталу та прямих інвестицій (UVCA). Загальна сума венчурних, прямих й ангельських інвестицій в 2016 році склала 88 млн. дол. Таким чином, обсяг розкритих інвестицій (13 угод були нерозкритими) зменшився на 33\% порівняно з 2015 роком [3].

Особливістю інвестиційного ринку в 2016 році стало те, що інвестори були більш сконцентровані на вкладанні коштів в компанії на початковому, «посівному» (seed) етапі. Таких угод було 73, а середній розмір інвестиції в одну компанію склав більше 500 тис. дол. Можна очікувати, що компанії, які зараз отримали «стартовий капітал», будуть в майбутньому залучати інвестиції більших обсягів [7].

5. Низький якісний рівень відповідної інфраструктури (транспортної, фінансової тощо), що виступає в ролі додаткового стримуючого фактору для іноземних інвесторів (потенційних покупців стартапів).

6. Невисока якість стартап-освіти в Україні. Стартап-школи в Україні $\epsilon$, але часто підготовка в них зводиться до переповідання історій досягання успіху успішними стартаперами чи власниками діючого бізнесу 3 намаганням дати слухачам правильні відповіді на їхні питання 3 урахуванням галузевої специфіки бізнесу. При цьому вбачається логічною позиція Джеймса O'Тула, який вважає, що для того, щоб знайти відповіді на складні питання, ми повинні відмовитися від пошуку миттєвих практичних ріред, зрозуміти базові ідеї та цінності, які формують світ, в якому ми працюємо. Той, хто вимагає конкретних інструкцій на всі випадки життя, знаходиться за визначенням на найближчій стороні складності. Це означає, що стартап-освіта повинна бути інтегрована в систему професійної менеджмент-освіти, такої, яка $\epsilon$ індиферентною до галузевого поділу економіки та яка формує слухачам системний погляд на управлін-

Вищевказаний перелік проблем управління стартапами не $\epsilon$ вичерпним, проте дає змогу окреслити основні перешкоди стартапам в Україні, а також розробити відповідні шляхи подолання даних перешкод задля ефективної реалізації потенціалу стартапдіяльності.

Висновки та перспективи подальших досліджень. На основі проведеного дослідження є можливими наступні висновки.

3-поміж багатьох питань стосовно перспектив розвитку стартапів в Україні необхідно виділити наступні:

1. Через потужний аграрний потенціал України може бути доцільним спеціалізувати стартапшень. Як це не парадоксально, ми повинні насампеня бізнесом.

діяльність на реалізації саме аграрних проектів і проектів в суміжних галузях, наприклад, харчовій промисловості. Незважаючи на пожвавлення інвестиційної діяльності в аграрному секторі, дані проекти не характеризуються високою наукоємністю та інноваційністю, і в той час, коли стартапи фірм Західної Європи та Світу працюють в напрямку полікомпонентних напівфабрикатів, нанотехнологій для харчових продуктів, органічного землеробства, надточного прогнозу погоди для фермерів у вигляді мобільних додатків тощо, вітчизняні проекти тяжіють до екстенсивної діяльності з певною часткою автоматизації робіт.

2. Конче необхідним є налагодження сталої взаємодії стартаперів 3 наукою, державою та інституціями менеджмент-консалтингу (в тому числі i, насамперед, дорадництва, якщо враховувати актуальність напрямків, зазначених в попередньому пункті), що буде передумовою для виникнення синергетичного ефекту в точках взаємодії вказаних суб'єктів. Прикладів ефективної взаємодії такого формату в світовій чи європейській практиці бізнесу є чимало, один 3 яких - польський виробник високотехнологічних тепличних комплексів та садових центрів - компанія «Agro-Sur», яка свого часу, будучи стартапом, налагодивши двосторонній зв'язок 3 науковцями, наразі реалізує на теренах Європи проекти інноваційного садівництва для бізнесу, вищих навчальних закладів відповідного спрямування, держави.

3. Повна реалізація стартап-потенціалу України $\epsilon$ неможливою без ефективно функціонуючої системи менеджмент-освіти та відповідної інфраструктури, яка представлена, насамперед, якісною мережею доріг, стабільною банківською системою, простою та стабільною системою оподаткування. Без зазначених складових сучасної ринкової економіки, перспективи стартап-діяльності в Україні є вкрай невиразними.

4. Особливо важливою може бути практична значущість результатів даного дослідження для органів державної влади, в разі використання ключових пропозицій стосовно професіоналізації управління економікою 3 урахуванням специфіки стартапдіяльності, i, насамперед, стосовно налагодження взаємодії професійного ланцюжка «освіта-бізнесдержава».

Перспективами для подальших досліджень $є$ питання регіональних аспектів стартап-діяльності в Україні, можливості використання закордонного досвіду в державному регулюванні сфери стартапів тощо.

\section{Література}

1. Бланк С. Стартап. Настольная книга основателя / Стив Бланк, Боб Дорф; пер. с англ. - М.: Альпина Паблишер, 2013. - 616 с.

2. Збанацький Д. Стартапи: юридичні та практичні аспекти [Електроний ресурс] / Д. Збанацький // Незалежний аудитор. - $\quad$ №3(14). $\quad$ - $2013 . \quad$ - $\quad$ Режим доступу: http://nauditor.com.ua/uk/component/na_archive/155?view=material

3. Івашова Н.В. Start up проекти - інструмент реалізації інновацій / Н.В. Івашова // Економічні проблеми сталого розвитку: міжнар. наук. - практич. конф., 24-26 квітня 2013 р.: тези доповіді. - Суми, 2013. - Т.4. C. 115-116. 
4. Красильникова Ю. Рынок искусственного мяса достигнет \$5 млрд к 2020 году [Електроний ресурс] / Ю. Красильникова // Хайтек. - 2017. - Режим доступу: https://hightech.fm/2017/05/10/fake meat lobby

5. Кузнецов Е.А. Професіоналізація управлінської діяльності: система, механізм та інноваційна динаміка: [монографія] / Е.А. Кузнецов. - Одеса: Наука і техніка, 2015. - 368 с.

6. Лалу Ф. Компанії майбутнього / Фредерік Лалу ; пер. з англ. Романа Клочко. - Х.: КСД, 2017. - 544 с.

7. Мрихіна О. Б. Перспективи стартап-компаній у контексті конкурентоспроможного розвитку українського ринку високих технологій / О. Б. Мрихіна, А.Р. Стояновський, Т.І. Міркунова // Актуальні проблеми економіки. - 2015. - №9 (171). - С. 215-225

8. Сісодіа Р., Вольф Девід Б., Шет Д. Фірми, що несуть любов. Як компаніям зі світовим ім'ям вдається завойовувати серця людей / Сісодіа Раджендра С., Вольф Девід Б., Шет Джагдіш Н. ; пер. $з$ англ. за наук. ред. канд. економ., наук І.В. Тараненко. - Дніпропетровськ: Баланс Бізнес Букс, 2011. - 336 с.

9. Тіль П. Від нуля до одиниці. Нотатки про стартапи, або як створити майбутнє / Пітер Тіль ; пер. 3 англ. Р. Обухів. - К.: Наш формат, 2015. - 232 с.

10. Ries E. The lean startup / Eric Ries // Crown Business, 2011. - 242 p.

Стаття надійшла 16.09.2017

Стаття прийнята до друку 29.09.2017

Доступно в мережі Internet 30.12.2017

Колесник В.И.

кандидат экономических наук, доцент кафедра управления бизнесом

Одесская национальная академия пищевых технологий

ул. Канатная, 112, м. Одеса, Украина, 65039

E-mail: brig_od@i.ua

\section{УПРАВЛЕНИЕ СТАРТАПАМИ В УКРАИНЕ: ПРОБЛЕМЫ И ПЕРСПЕКТИВЫ}

В статье рассмотрены особенности теории и практики управления стартапами в Украине.

На основании исследования множества определений стартапа как экономической категории, предложена его авторская интерпретация с учетом таких специфических черт как иноязычное происхождение и временные рамки практической реализации стартапов в Украине.

Критическому анализу поддан ряд признаков стартапов. Некоторые из таких признаков, по мнению автора нецелесообразно применять для идентификации именно стартапа как особой фрормы бизнес-проекта. В силу этого систематизирован ряд ключевых признаков (в особенности «инновационности» как характеристики стартапа). Это призвано способствовать повышению эффективности управленческой работы в стартапах.

Определяются актуальные проблемы, которые связаны с функционированием стартапов. При этом выделены проблемы макроуровня, связанные с эффективностью государственного управления экономикой вцелом, а также - проблемы микроуровня, которые обусловлены качеством менеджмента конкретного предприятия.

Указываются пути преодоления проблем. На примерах показан европейский (в частности польских управленцев) опыт профессионализации управления стартапами как со стороны государства, так и непосредственно менеджмента стартапов. При этом в статье акцентировано внимание на возможности и необходимости активизации стартап-деятельности в аграрной сфере, что может иметь особое значение, учитывая, с одной стороны актуализацию глобальных проблем обеспечения человечества продовольствием, а с другой - традиционно внушительный потенциал Украины в сфере агробизнеса и пищевой промышленности.

Проанализирован потенциал менеджмент-образования как базовой предпосылки профессионализации управления стартапами в Украине.

Предложен системный подход к повышению эффективности управления стартапами, обоснована перспективность его дальнейшей апробации с позиций реализации инновационного потенциала экономики Украины.

Ключевые слова: стартап, управление, эффективность стартапов, проблемы стартапдеятельности, перспективы стартапов в Украине. 


\author{
Kolesnik V. \\ Ph.D., Associate Professor \\ Department of Business Administration \\ Odessa National Academy of Food Technologies \\ Kanatna str., 112, Odessa, Ukraine, 65039 \\ E-mail: brig_od@i.ua
}

\title{
MANAGEMENT OF STARTUPS IN UKRAINE: PROBLEMS AND PROSPECTS
}

The peculiarities of the theory and practice of management of startups in Ukraine have been considered in this article.

On the basis on the investigation of a large number of definitions of a startup as an economic category, his author's interpretation taking into account of such specific features as foreign origin and temporal limits of the practical realization of startups in Ukraine, has been suggested.

A number of signs of startups have been subjected to the critical analysis. Some of these signs according to the author are inexpediently applied for identification the startup as a special form of a business project. As a result of these, a number of key signs (especially "being innovative" as a starter characteristic) has been systemized it's designed to contribute to increase of management work efficiency in startups.

The urgent problems, which are connected with functioning of startups, are determined as this, the problem of macrolevel, connected with efficiency of state management of the economy as a whole as well as the problems of microlevel, which are stipulated by the quality of the particular enterprise management, have been painted out. The ways of coping with the problems have been determined.

The European (in particular Polish managers') experience of making management of the startups professional, both from the government's side and directly from the management of startups has been shown on their examples. On this, the attention has been paid to the possibility and necessity of activization of startups activities in the agrarian field, that may have a special importance, taking into account on the one hand urgency of the global problems of providing the mankind with food products, on the other hand traditionally impressive potential of Ukraine in the field of agrobusiness and food industry.

The potential of management education as a basic precondition of making management of startups in Ukraine professional has been analyzed.

The system approach to increase of the efficiency of management of startups has been proposed, the prospects of its further approbation from a position of realization of their innovative potential of Ukrainian economy have been stipulated.

Keywords: startup, management, efficiency of startups, problems of startup activity, prospects of startups in Ukraine.

\section{References}

1. Blank, S., \& Dorf, B. (2013). Nastolnaya kniga osnovatelya. Alpyna Pablysher.

2. Zbanatskyi, D. (2013). Startapy: yurydychni ta praktychni aspekty. Nezalezhnyi audytor, (3 (14)). Retrieved from http://n-auditor.com.ua/uk/component/na archive/155?view=material

3. Ivashova, N. V. (2013). Start up proekty - instrument realizatsii innovatsii. In Ekonomichni problemy staloho rozvytku: mizhnar. nauk. - praktych. konf. (Vol. 4, pp. 115-116). Sumy.

4. Krasilnikova, Yu. (2017). Ryinok iskusstvennogo myasa dostignet \$5 mlrd k 2020 godu. Retrieved from https://hightech.fm/2017/05/10/fake_meat_lobby

5. Kuznetsov, E. A. (2015). Profesionalizatsiia upravlinskoi diialnosti: systema, mekhanizm ta innovatsiina dynamika. Odesa.

6. Lalu, F. (2017). Kompanii maibutnoho (R. Klochko, Trans.). KSD

7. Mrykhina, O. B. (2015). Perspektyvy startap-kompanii u konteksti konkurentospromozhnoho rozvytku ukrainskoho rynku vysokykh tekhnolohii. Aktualni problemy ekonomiky, (9 (171)), 215-225.

8. Sisodia, R. S., Volf D. B., \& Shet, D. N. (2011). Firmy, shcho nesut liubov. Yak kompaniiam zi svitovym im'iam vdaietsia zavoiovuvaty sertsia liudei (I. V. Taranenko, Ed.). Dnipropetrovsk: Balans Biznes Buks.

9. Til, P. (2015). Vid nulia do odynytsi. Notatky pro startapy, abo yak stvoryty maibutnie (R. Obukhiv, Trans.). Nash format.

10. Ries, E. (2011). The lean startup. Crown Business.

Received 16 September 2017 Approved 29 September 2017 Available in Internet 30.12.2017 